\title{
Deficiency of ER $\beta$ and prostate tumorigenesis in FGF8b transgenic mice
}

\author{
Teresa Elo', Lan Yu', Eeva Valve², Sari Mäkelä ${ }^{3,4}$ and Pirkko Härkönen ${ }^{1,5}$ \\ Departments of ${ }^{1}$ Cell Biology and Anatomy ${ }^{2}$ Pharmacology, Drug Development and Therapeutics and ${ }^{3}$ Turku Center \\ for Disease Modeling, Institute of Biomedicine, University of Turku, Kiinamyllynkatu 10, 20520 Turku, Finland \\ ${ }^{4}$ Functional Foods Forum, University of Turku, Turku, Finland \\ ${ }^{5}$ Department of Laboratory Medicine, MAS University Hospital, Lund University, Malmö, Sweden
}

Correspondence should be addressed to T Elo

Email

teresa.elo@utu.fi

\begin{abstract}
Estrogens contribute to the development and growth of the prostate and are implicated in prostate tumorigenesis. In their target tissues, estrogens mediate their effects via estrogen receptor $\alpha(E R \alpha(E S R 1))$ and $\beta$ (ER $\beta(E S R 2))$. Hyperplasia and decreased differentiation of epithelial cells in the prostate have been reported in $E R \beta$ knockout (BERKO) mice. Herein, we studied the effect of ER $\beta$ deficiency on prostate tumorigenesis by crossing $\mathrm{BERKO}_{\mathrm{FVB}}$ mice with prostate-targeted human fibroblast growth factor $8 \mathrm{~b}$ transgenic ( $F G F 8 b-\mathrm{Tg}$ ) mice. Consistent with results described in our previous report, the prostates of 1-year-old FGF8b-Tg mice displayed stromal aberrations, prostatic intraepithelial neoplasia (MPIN) lesions, inflammation, and occasionally cancer. The prostates of $\mathrm{BERKO}_{\mathrm{FVB}}$ mice exhibited mild epithelial hypercellularity and inflammation. The prostate phenotypes of FGF8b-Tg-BERKO ${ }_{\mathrm{FVB}}$ mice closely resembled those of $F G F 8 b$-Tg mice. However, mucinous metaplasia, indicated by Goblet-like cells in the epithelium, was significantly more frequent in the prostates of FGF8b-Tg-BERKO $\mathrm{FVB}_{\mathrm{FB}}$ mice when compared with FGF8b-Tg mice. Furthermore, compared with FGF8b-Tg mice, there was a tendency for increased frequency of inflammation but milder hyperplasias in the prostate stroma of $F G F 8 b-T g-B_{E R K O} \mathrm{FVB}$ mice. The expression levels of mRNAs for FGF8b-regulated genes including osteopontin (Spp1), connective tissue growth factor (Ctgf), fibroblast growth factor receptors ( $F g f r s)$, and steroid hormone receptors and cytokines were similar in the prostates of $F G F 8 b-\mathrm{Tg}$ and $F G F 8 b-\mathrm{Tg}-\mathrm{BERKO}_{\mathrm{FVB}}$ mice. Our results indicate that ER $\beta$ plays a role in the differentiation of the prostatic epithelium and, potentially, in the defensive mechanism required for protection against inflammation but do not support a direct tumor-suppressive function of ER $\beta$ in the prostate of FGF8b-Tg mice.
\end{abstract}

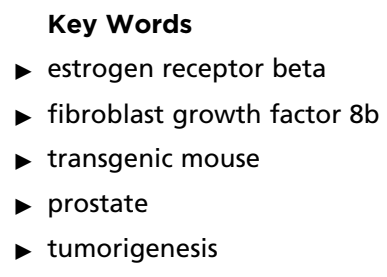

Endocrine-Related Cancer (2014) 21, 677-690

\section{Introduction}

Estrogens can affect the development of the prostate and prostate tumorigenesis. Exposure to high levels of circulating estrogens during in utero development and aging has been shown to affect the prostate and may contribute to the development of benign prostatic hyperplasia (BPH) and prostate cancer (Härkönen \& Mäkelä 2004, Prins \& Korach 2008, Ellem \& Risbridger 2009, Hartman et al. 2012).

In target tissues, estrogens act via estrogen receptor $\alpha$ $(\mathrm{ER} \alpha)(\mathrm{ESR} 1)$ and ER $\beta$ (ESR2), which are nuclear receptors encoded by separate but structurally homologous genes

Published by Bioscientifica Ltd. 
(Greene et al. 1986, Kuiper et al. 1996, Tremblay et al. 1997). In the prostate, ER $\alpha$ and ER $\beta$ are expressed in different compartments: $E R \alpha$ is expressed in the stroma, and ER $\beta$ is expressed primarily in the epithelium (Schulze \& Claus 1990, Prins \& Birch 1997, Prins et al. 1998, Mäkelä et al. 2000). Moreover, evidence from several in vitro and in vivo studies indicates that the two ERs have opposing functions in the prostate; $E R \alpha$ promotes proliferation, inflammation, and the development of dysplasia, whereas ER $\beta$ promotes differentiation and has anti-proliferative and anti-inflammatory effects (Prins et al. 2001, Risbridger et al. 2001, McPherson et al. 2007, Savolainen et al. 2007, Ricke et al. 2008, Slusarz et al. 2012, Dey et al. (In Press)). Based on the prostate phenotypes of conditional Er $\alpha$ knockout (ERKO) mice, ER $\alpha$ is required for the normal branching morphogenesis of the prostate and for maintaining fibroblast proliferation in the prostatic stroma (Chen et al. 2009). Interestingly, the reports on the prostate phenotype of the BERKO mice have been conflicting. Some studies have reported epithelial hyperplasia, increased proliferation (Weihua et al. 2001), inflammation (Prins \& Korach 2008), and an elevated number of basal cells in the prostate of BERKO mice (Imamov et al. 2004), but other studies did not find any prostate phenotype in the BERKO mouse models (Dupont et al. 2000, Prins et al. 2001, Antal et al. 2008).

Several functionally different isoforms of human ER $\beta$ (hERß1-5) exist (Moore et al. 1998, Leung et al. 2006). Studies have reported a decreased level of hER $\beta$ in prostatic intraepithelial neoplasia (PIN) lesions or in prostate cancer, supporting the tumor-suppressive role of ER $\beta$ (Horvath et al. 2001, Leav et al. 2001, Pasquali et al. 2001, Fixemer et al. 2003, Muthusamy et al. 2011). According to Zhu et al. (2004), the loss of ER $\beta$ expression during prostate tumorigenesis is epigenetically regulated by the hypermethylation of $\mathrm{CpG}$ islands in the ER $\beta$ promoter. On the other hand, a high level of ER $\beta$ expression has been reported in advanced prostate cancer (Horvath et al. 2001, Leav et al. 2001, Torlakovic et al. 2002, Walton et al. 2009) and in prostate cancer metastasis (Fixemer et al. 2003). The conflicting results regarding the expression of ER $\beta$ during prostate tumorigenesis in different studies can be at least partly explained by the use of different antibodies, which were either specific for the hER $\beta 1$ isoform or recognized all or several hER $\beta$ isoforms, which have differential functions (Leung et al. 2006). Recent results have indicated that the different isoforms of ER $\beta$ have different functions in prostate tumorigenesis. hER $\beta 1$ has a tumor-suppressive role, while hER $\beta 2$ and hER $\beta 5$ are oncogenic and promote the proliferation, invasion, and metastasis of prostate cancer cells (Leung et al. 2010, Dey et al. 2012). The results regarding the expression of $\mathrm{ER} \alpha$ in human prostate cancer are also conflicting; some reports have indicated an increase in the expression of $\mathrm{ER} \alpha$ during prostate tumorigenesis (Bonkhoff et al. 1999), but others have found that ER $\alpha$ expression is silenced by promoter methylation in early prostate cancers (Lau et al. 2000, Li et al. 2000).

The purpose of this study was to evaluate the potential role of ER $\beta$ in prostate tumorigenesis and the relationship between ER $\beta$ and FGF signaling in a novel mouse model. We have reported previously that overexpression of prostate-targeted of human fibroblast growth factor $8 \mathrm{~b}$ (FGF8b) in Tg mice leads to the development of epithelial and stromal hypercellularity, which progresses with age to preneoplastic and neoplastic lesions such as mPIN, adenocarcinoma, and sarcoma in the prostate (Elo et al. 2010). To examine as to whether the deficiency of ER $\beta$ accelerates the process of tumorigenesis observed in the $F G F 8 b$-Tg mice or provides a more severe prostate phenotype, $F G F 8 b$-Tg mice were crossed with $\mathrm{BERKO}_{\mathrm{FVB}}$ mice, and the prostate histology and expression of genes in the prostate of the resultant hybrid mice were carefully examined.

\section{Materials and methods}

\section{Animal experiments}

$F G F 8 b$-Tg mice in the $\mathrm{FVB} / \mathrm{N}$ strain were generated in our laboratory as described previously (Elo et al. 2010). BERKO mice, generated by conventional knockout techniques in the C57BL/6J strain (Krege et al. 1998), obtained from Jan-Åke Gustafsson (Karolinska Institutet, Sweden), were crossbred with $\mathrm{FVB} / \mathrm{N}$ mice for seven generations to produce $\mathrm{BERKO}_{\mathrm{FVB}}$ mice. Generation of $F G F 8 b$-Tg-ER $\beta^{-1-}$ $\left(F G F 8 b\right.$-Tg-BERKO $\left.\mathrm{FVB}_{\mathrm{B}}\right)$ mice by crossings in two generations is described in detail in Supplementary Figure 1, see section on supplementary data given at the end of this article. The genotyping for both genomic modifications has been described previously (Windahl et al. 1999, Elo et al. 2010). Male mice with the FGF8b-Tg-BERKO ${ }_{\mathrm{FVB}}$, $F G F 8 b$-Tg, BERKO $\mathrm{FVB}$, and WT genotypes were kept until the age of 12-16 months and housed under controlled environmental conditions ( $12 \mathrm{~h}$ light: $12 \mathrm{~h}$ darkness cycle at a temperature of $21 \pm 3{ }^{\circ} \mathrm{C}$ ). Pelleted chow (RM1(E)SQC, 811002, SDS) and tap water were offered and animals were allowed to feed ad libitum. Mice were killed by $\mathrm{CO}_{2}$ asphyxiation and cervical dislocation.

Published by Bioscientifica Ltd. 
Animal experiments performed in this study were approved by the National Animal Experiment Board. For gene expression studies, prostate lobes (ventral, anterior, and dorsolateral prostate; VP, AP, and DLP respectively) were dissected and frozen in liquid nitrogen. For histological preparations, prostate blocks were removed and fixed in 10\% neutral buffered formalin. The fixed tissues were embedded in paraffin, and sections of $5 \mu \mathrm{m}$ thickness were prepared for standard hematoxylin and eosin (HE), Periodic Acid-Schiff (PAS), Masson's trichrome, and immunohistochemical (IHC) staining.

\section{Histological analysis}

Histological analysis was performed in a blinded manner from the HE-stained prostate sections of a total of 52 mice (eight WT, 12 BERKO $_{\mathrm{FVB}}, 21 F G F 8 b$-Tg, and 11 $F G F 8 b$-Tg-BERKO $\mathrm{FVB})$ between the ages of 10 and 14.5 months. Sections from several levels of the VP and DLP were evaluated. The degree of inflammation (on a scale of 0-3) was evaluated by analyzing the mean number of lymphocyte aggregates in the prostate stroma as described previously (Elo et al. 2010).

\section{IHC staining}

The procedures for IHC staining for the androgen receptor (AR) and alpha smooth muscle actin (Acta2, hereafter referred to as SMA) have been described previously (Elo et al. 2010). For the staining for p63, a mouse monoclonal anti-p63 antibody BD Pharmingen (4A4) was used at a 1:500 dilution. The antigens were retrieved in $10 \mathrm{mM}$ citric acid buffer, $\mathrm{pH} 6$, in a microwave oven. The frequency of AR-positive cells was evaluated from sections stained by AR IHC ( $n=6-8 /$ mouse group) by estimating the percentage of positively stained nuclei in the VP epithelium and stroma separately in the areas with normal, hypercellular, atypical, dysplastic, or malignant histology. For each histological phenotype, 4-6 microscopic fields (using a $20 \times$ objective) were analyzed if

Table 1 Sequences of primers used in qRT-PCRs

\begin{tabular}{|c|c|}
\hline Genes & Forward primers $\mathbf{5}^{\prime}-\mathbf{3}^{\prime}$ \\
\hline$A r$ & GTCTCCGGAAATGTTATGAA \\
\hline$E r \alpha$ & CCGTGTGCAATGACTATGCC \\
\hline //17a & TCATCCCTCAAAGCTCAGCG \\
\hline $1 / 6$ & CCGGAGAGGAGACTTCACAG \\
\hline Muc1 & GTGCCAGTGCCGCCGAAAGA \\
\hline Muc2 & GCCAGATCCCGAAACCAC \\
\hline Tgfb1 & CAACAATTCCTGGCGTTACCTTGG \\
\hline Tnf & CCCCAAAGGGATGAGAAGTT \\
\hline
\end{tabular}

available; otherwise, the total available area was analyzed. ER $\beta$ was detected from methanol-fixed frozen sections of $\mathrm{AP}$ and DLP using a polyclonal anti-mouse ER $\beta$ antibody (Santa Cruz, Y19, sc-6821) recognizing a peptide from the $\mathrm{N}$-terminus of ER $\beta$. Alexa Fluor 594 donkey anti-goat IgG (A-11058) was used as a secondary antibody.

\section{RNA extraction and quantitative RT-PCR}

RNA extraction from the VPs and DNase treatment were performed as described previously (Elo et al. 2012). The reagents and machinery for quantitative RT-PCR (qRT-PCR) have been described previously (Elo et al. 2012). The sequences of the primers and annealing temperatures used in qRT-PCR are given in Table 1.

\section{Statistical analysis}

Statistical analyses were performed using the SPSS 11.0 software for Windows (SPSS) and GraphPad Prism 6 (Graphpad Software, Inc., San Diego, California, USA). Differences in the frequencies of the histological changes between $F G F 8 b$-Tg and $F G F 8 b$-Tg-BERKO ${ }_{\text {FVB }}$ mice were tested using the $\chi^{2}$-test. For qRT-PCR results, the normal distribution of the data was tested using the Shapiro-Wilk $W$-test. Then, either an ANOVA (one-way ANOVA) corrected by Tukey's multiple comparison test or a Kruskal-Wallis test corrected by Dunn's multiple comparison test were applied. The values with $P<0.05$ were considered to be statistically significant.

\section{Results}

\section{FGF8b-Tg-BERKO ${ }_{\mathrm{FVB}}$ mice have abnormalities in their prostates and other urogenital organs}

$F G F 8 b$-Tg and $\mathrm{BERKO}_{\mathrm{FVB}}$ mice were successfully bred, and the genotypic distribution of the offspring was as expected. The offspring of all the genotypes, including the $F G F 8 b$-Tg-BERKO $\mathrm{FVB}_{\text {B }}$ mice, were viable and

\begin{tabular}{l} 
Reverse primers $\mathbf{5}^{\prime} \mathbf{- 3}^{\prime}$ \\
\hline AAGCTGCCTCTCTCCAAG \\
GTGCTTCAACATTCTCCCTCCTC \\
TTCATTGCGGTGGAGAGTCC \\
CAGAATTGCCATTGCACAAC \\
TGCCGAAACCTCCTCATAGGGGC \\
TGTAGGAGTCTCGGCAGTCA \\
GAAAGCCCTGTATTCCGTCTCCTT \\
CACTTGGTGGTTTGCTACGA
\end{tabular}
Annealing temperature $\left({ }^{\circ} \mathrm{C}\right)$ 58 58 58 60 60 60 60 60 
phenotypically normal. The prostate and other urogenital organs of the $\mathrm{BERKO}_{\mathrm{FVB}}$ mice were macroscopically normal. The prostates and in some cases the epididymides and testes of the $F G F 8 b$-Tg-BERKO ${ }_{\mathrm{FVB}}$ mice were enlarged and/or had an abnormal appearance, as described previously for the FGF8b-Tg mice (Elo et al. 2010, 2012).

\section{Increased frequency of mucinous metaplasia in the prostates of $F G F B b-T G-B E R K O_{\mathrm{FVB}}$ mice}

Histological evaluation revealed mild changes in the VP and DLP of 1-year-old $\mathrm{BERKO}_{\mathrm{FVB}}$ mice. Compared with WT mice, the prostates of the $\mathrm{BERKO}_{\mathrm{FVB}}$ mice displayed a tendency to increased frequency of focal epithelial hypercellularity (38 vs 58\%) and inflammation (13 vs $33 \%$ ), presented as aggregates of lymphocytes in the prostatic stroma (Fig. 1A, B, C, and D); the prostates were otherwise normal (Fig. 1A).

Consistent with results described in our previous report (Elo et al. 2010), the VP and DLP of the 1-year-old $F G F 8 b$-Tg mice contained a high frequency of epithelial and stromal abnormalities (Fig. 1A) such as epithelial and stromal hypercellularities with atypical cells, mPIN lesions, and inflammation (Fig. 1E). Prostatic adenocarcinoma was present in one FGF8b-Tg mouse, and either sarcoma or carcinosarcoma was present in $10 \%$ of the FGF $8 b$-Tg mice (Fig. 1A).

The frequency of histological changes and the presence of those changes in VP and DLP were mostly similar in the prostates of $F G F 8 b$-Tg-BERKO $\mathrm{FVB}_{\mathrm{B}}$ and FGF8b-Tg mice (Fig. 1A, E, and F). However, mucinous metaplasia foci, defined by Goblet-like cells in the prostate epithelium in the HE-stained sections, were significantly more frequent $\left(\chi^{2}\right.$-test, $P=0.028$ ) in the $F G F 8 b$-Tg-BERKO ${ }_{\text {FVB }}$ mice than in FGF $8 b$-Tg mice (82 vs $38 \%$ ) (Fig. 1A). PAS staining, which stains neutral and acidic mucins, verified the presence of mucin-secreting cells in the epithelium of the majority of $F G F 8 b$-Tg (71\%) and FGF $8 b$-Tg-BERKO ${ }_{\mathrm{FVB}}$ (89\%) prostates that were defined as goblet-cell-positive in the initial analysis (Fig. 1I and J). In contrast, the majority of BERKO $\mathrm{FVB}$ $(100 \%)$ and WT $(67 \%)$ prostates that were defined as goblet-like-cell-positive did not contain PAS-positive cells in their epithelia (Fig. $1 \mathrm{G}$ and $\mathrm{H}$ ). In addition, inflammation was slightly, but not to a statistically significant extent, more frequent in the prostates of $F G F 8 b$-Tg-BERKO ${ }_{\mathrm{FVB}}$ mice than in the prostates of $F G F 8 b$-Tg mice ( 82 vs $62 \%$ ). The mean score for inflammation (on a scale of $0-3$ ) was similar in the prostates of $F G F 8 b$-Tg and FGF8b-Tg-BERKO $\mathrm{FVB}_{\mathrm{F}}$ mice (0.9 vs 1.0) (Fig. 1B). Epithelial and stromal hypercellularities were present at similar frequencies in the prostates of $F G F 8 b$-Tg and $F G F 8 b$-Tg-BERKO ${ }_{\mathrm{FVB}}$ mice (90 vs $100 \%$ and 57 vs $64 \%$ respectively). However, the hypercellular stroma seemed to be more extensive in the prostates of $F G F 8 b$-Tg mice when compared with the $F G F 8 b$-Tg-BERKO ${ }_{\text {FVB }}$ mice (Fig. 1E, F, I, and J). In addition, both epithelial and stromal hypercellularities containing atypical cells were slightly increased in the prostates of $F G F 8 b$-Tg mice compared with $F G F 8 b$-Tg-BERKO ${ }_{\text {FVB }}$ mice ( 67 vs $55 \%$ and 38 vs $27 \%$ respectively), but the differences between the groups were not statistically significant. In contrast to $F G F 8 b$-Tg mice, malignant changes were not found in the $F G F 8 b$-Tg-BERKO $\mathrm{FVB}_{\text {B }}$ prostates (adenocarcinomas 5 vs $0 \%$; sarcomas or carcinosarcomas, 10 vs $0 \%$ ) (Fig. 1A).

\section{Alterations in the prostate stroma of $F G F 8 b-T G-B E R K O_{\mathrm{FVB}}$ mice}

To examine whether there were changes in the percentage of basal cells, indicative of cellular differentiation in the prostate epithelium, ICH staining for p63 was performed (Fig. 2). An increased percentage of p63-positive cells in the prostate epithelium of BERKO mice has been reported previously (Imamov et al. 2004). Our results indicated that in particular the hypercellular foci of the prostate epithelium in $\mathrm{BERKO}_{\mathrm{FVB}}$ mice contained a high frequency of p63-positive cells (Fig. 2B). In contrast, in the prostate epithelium of $F G F 8 b$-Tg mice, there was a trend toward a decreased number of p63-positive cells, especially in foci containing mPIN lesions (Fig. 2C). The prostate epithelium of the FGF8b-TG-BERKO ${ }_{\mathrm{FVB}}$ mice contained some areas with an increased frequency of p63-positive cells and others with a decreased frequency of p63-positive cells (Fig. 2D). However, when larger areas of the VP were analyzed, no statistically significant differences in the percentage of p63-positive cells in the prostate epithelium were found between any of the mouse groups (Fig. 2E).

Staining for the AR was performed to examine whether there were changes in the percentage of AR-positive cells in the prostates of the studied mice, as has previously been described in FGF8b-Tg mice (Elo et al. 2010). A total of $90-100 \%$ of the normal prostate epithelial cells were positive for AR in all mouse groups (Fig. 3A, B, C, and D). A similarly high percentage of AR-positive cells was also present in the hypercellular areas of the prostate epithelium of a BERKO $\mathrm{FVB}_{\mathrm{VB}}$ mouse (Fig. 3B). Consistent with results described in our previous report (Elo et al. 2010), the percentage of AR-positive cells was often focally reduced (50-75\% of epithelial cells) in the PIN lesions of

Published by Bioscientifica Ltd 
A

Frequency, percentage of mice

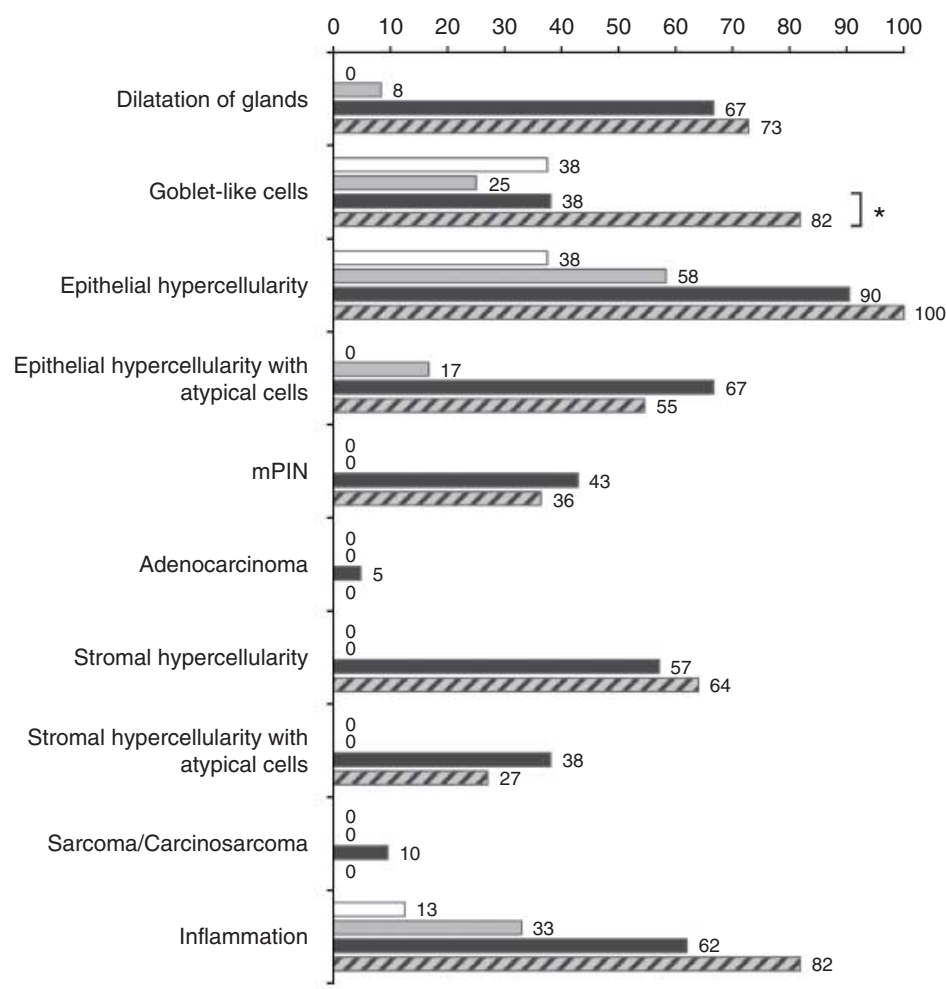

$\square$ WT, $n=8$
$\square$ BERKOFVB, $n=12$

Fgf8b-Tg, $n=21$

D Fgf8b-Tg-BERKOFVB, $n=11$
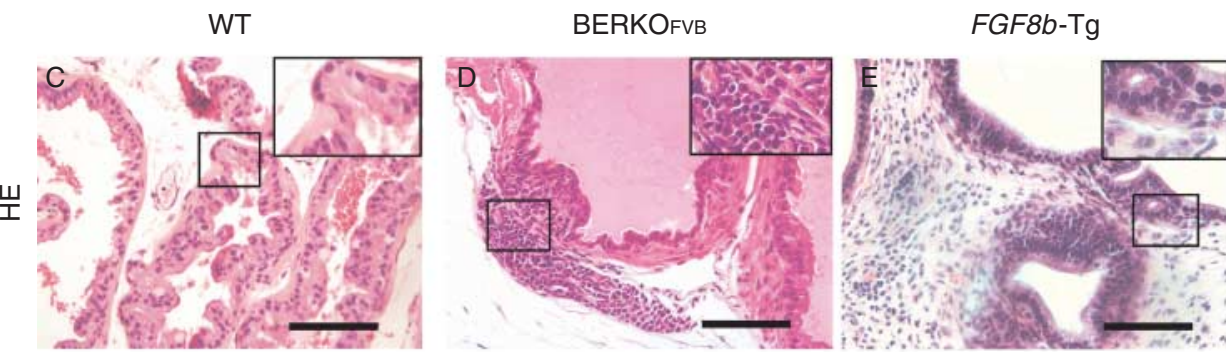

- WT, $n=8$

- BERKOFVB, $n=12$

- Fgf $8 b-\mathrm{Tg}, n=21$

- Fgf8b-Tg-BERKOFVB, $n=11$
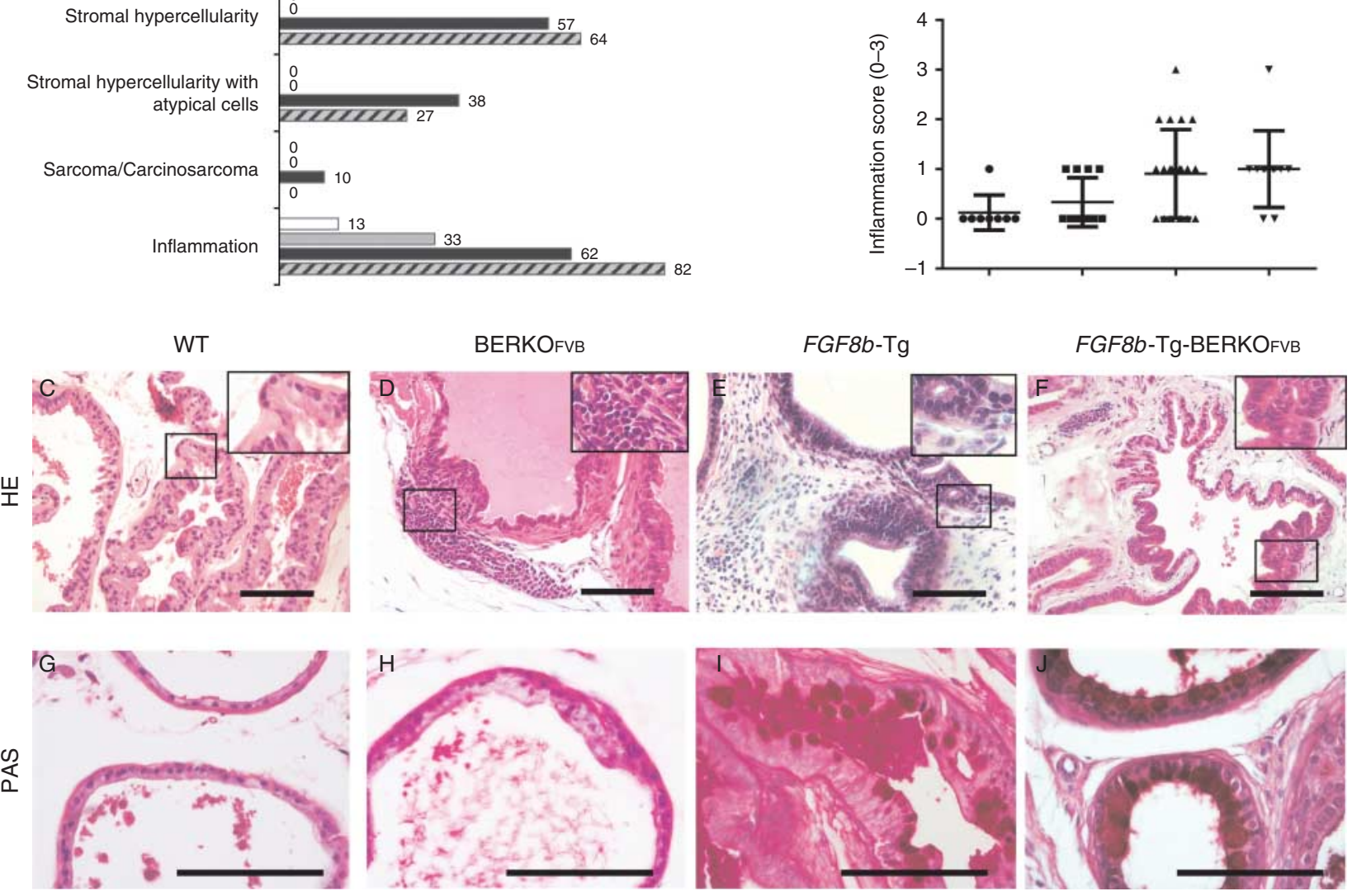

\section{Figure 1}

(A) Frequency of histological changes in the prostates of 10-14-month-old $\mathrm{WT}, \mathrm{BERKO}_{\mathrm{FVB}}, F G F 8 b-\mathrm{Tg}$, and $F G F 8 b$-Tg-BERKO $\mathrm{FVB}_{\mathrm{F}}$ mice. Differences in frequencies between FGF8b-Tg and FGF8b-Tg-BERKO ${ }_{\mathrm{FVB}}$ mice were tested by $\chi^{2}$-test. Exact $P$ values were used. $* P<0.05$. (B) The scores for inflammation in the mouse prostates evaluated on a scale of $0-3$ as defined in the Materials and methods section. The mean values and s.D.s are shown. (C) The normal histology of a 12.5-month-old WT mouse in the VP. (D) Inflammation displayed by an aggregate of lymphocytes in the VP stroma of a 14-month-old BERKO ${ }_{\mathrm{FVB}}$ mouse. (E) MPIN, stromal hypercellularity with atypia, and inflammation in the VP of a 12-month-old
FGF8b-Tg mouse. (F) mPIN, stromal hypercellularity, and inflammation in the VP of a 12-month-old FGF8b-Tg-BERKO ${ }_{\mathrm{FVB}}$ mouse. (G) PAS staining of a 10.5-month-old WT mouse VP showing no positive signal in the epithelium. (H) PAS staining of VP of a 13-month-old BERKO ${ }_{\mathrm{FVB}}$ mouse showing no positive staining in the epithelium. (I) PAS staining of VP of a 10.5-month-old FGF8b-Tg mouse showing positive PAS staining in the epithelial cells of an mPIN lesion. (J) PAS staining of VP of a 12.5-month-old FGF8b-Tg-BERKO ${ }_{\mathrm{FVB}}$ mouse showing PAS positivity in the epithelial cells. The images were obtained using $20 \times$ and $40 \times$ objectives. The scale bars represent $100 \mu \mathrm{m}$.

Published by Bioscientifica Ltd. 

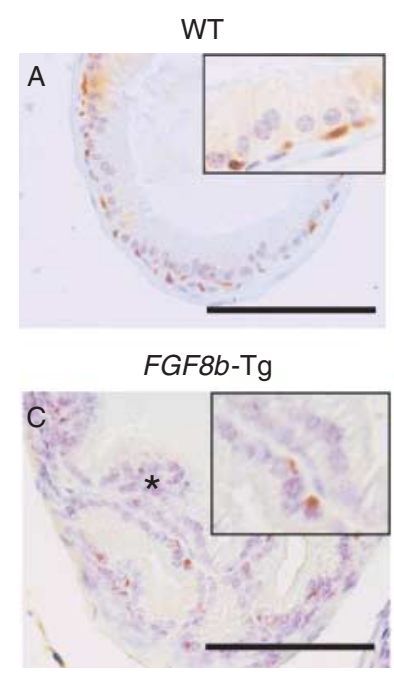

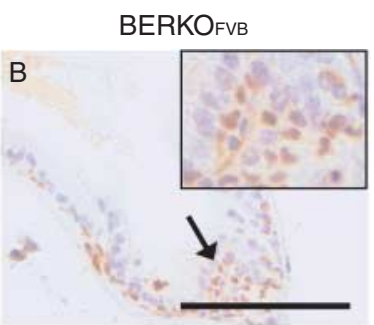

FGF8b-Tg-BERKOFVB

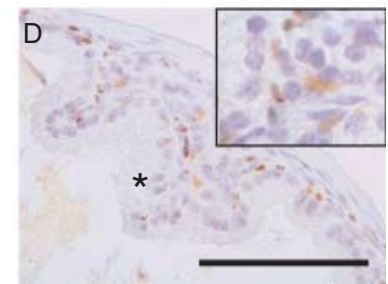

$\mathrm{E}$

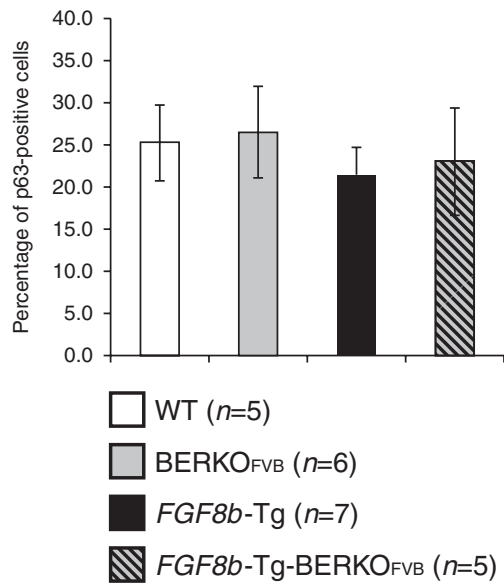

\section{Figure 2}

Immunohistochemical staining of p63 (basal cells) in the prostate epithelium. (A) A representative image of p63 staining in the normal VP epithelium of a 12-month-old WT mouse. (B) The hypercellular epithelium of a $\mathrm{BERKO}_{\mathrm{FVB}}$ mouse prostate with a focally increased frequency of p63positive cells (arrow). ( $C$ and D) A decreased frequency of p63-positive cells in the mPIN lesions (*) of FGF8b-Tg (C) and FGF8b-Tg-BERKO ${ }_{\mathrm{FVB}}$ mice (D). The images were obtained using a $40 \times$ objective, and the insets show

$F G F 8 b$ - Tg and $F G F 8 b$-Tg-BERKO $\mathrm{FvB}$ mice (Fig. 3C). In the normal prostate stroma, the percentage of AR-positive cells varied between 35 and 50\% in all mouse groups. These results were also consistent with findings described our previous report (Elo et al. 2010), the percentage of AR-positive cells was reduced in the hypercellular and atypical prostate stroma of $F G F 8 b$-Tg mice (10-40\% AR-positive cells) (Fig. 3C) and increased in the sarcomalike lesions (70\% AR-positive cells). However, in contrast, the percentage of AR-positive cells was more variable (15-75\% AR-positive cells) in the hypercellular stroma of $F G F 8 b$-Tg-BERKO $\mathrm{FvB}_{\mathrm{B}}$ mouse prostates (Fig. 3D).

The composition of prostate stroma was studied by IHC staining for SMA (Fig. 3E, F, G, and H) and by Masson's trichrome staining (Fig. 3I and J). The normal prostate stroma of the WT and BERKO $\mathrm{FVB}$ mice contained SMApositive cells in a ring-like structure surrounding the prostatic acini (Fig. 3E and F). The hypercellular stroma of both $F G F 8 b$-Tg and $F G F 8 b$-Tg-BERKO ${ }_{\mathrm{FVB}}$ mouse prostates contained SMA-negative areas surrounding the prostatic acini, but in $F G F 8 b$-Tg mice, these areas were frequently more extensive and more irregular than those in FGF8b-Tg-BERKO ${ }_{\mathrm{FVB}}$ mice (Fig. $3 \mathrm{G}$ and $\mathrm{H}$ ). The staining patterns were similar in the prostates of WT and $\mathrm{BERKO}_{\mathrm{FVB}}$ mice for Masson's trichrome staining, which stains collagen fibers blue-green and smooth muscle red
$2 \times$ magnification of the images. The scale bars represent $100 \mu \mathrm{m}$. (E) The percentages of p63-positive cells in the VP epithelia of WT, BERKO ${ }_{\mathrm{FVB}}$, FGF8b-Tg, and FGF8b-Tg-BERKO ${ }_{\mathrm{FVB}}$ mice. A minimum of one thousand epithelial cells from multiple prostatic acini from sections stained for p63 were analyzed by IHC ( $n=5-7 /$ mouse group). The mean values \pm s.D.s are shown. There were no statistically significant differences between the mouse groups (one-way ANOVA and Tukey's multiple comparison test).

(Fig. 3I and J). The hypercellular stroma in both FGF8b-Tg and $F G F 8 b$-Tg-BERKO $\mathrm{FVB}_{\text {B }}$ prostates contained wider areas of blue-green-staining (Fig. $3 \mathrm{~K}$ and L). However, in the prostate stroma of $F G F 8 \mathrm{~b}$-Tg mice, these areas were generally more extensive and the collagen fibers were less organized compared with the $F G F 8 b$-Tg-BERKO $\mathrm{FVB}_{\mathrm{F}}$ mice.

\section{Gene expression patterns in VPs of FGF8b-Tg-BERKO ${ }_{\mathrm{FVB}}$ and FGFBb-Tg mice}

To examine whether there were changes in the expression of genes that have been previously found to be upregulated in the VP and epididymides of FGF8b-Tg mice (Elo et al. 2010, 2012), such as osteopontin (Spp1) and connective tissue growth factor (Ctgf), we performed qRT-PCR analysis on the VPs of 10-16-month-old WT, $\mathrm{BERKO}_{\mathrm{FVB}}, F G F 8 b-\mathrm{Tg}$, and $F G F 8 b-\mathrm{Tg}-\mathrm{BERKO} \mathrm{FVB}_{\mathrm{FB}}$ mice (Fig. 4). The expression of FGF8b mRNA, which is an indicator of the function of the transgene construct, was increased by several hundred-fold in the prostates of $F G F 8 b$-Tg and $F G F 8 b$-Tg-BERKO ${ }_{\mathrm{FVB}}$ mice compared with WT and $\mathrm{BERKO}_{\mathrm{FVB}}$ mice (Fig. 4). Consistent with results described in our previous report (Elo et al. 2010), the expressions of Spp1 and Ctgf mRNAs were significantly upregulated in the prostates of FGF8b-Tg and FGF $8 b$-Tg-BERKO $\mathrm{FV}_{\mathrm{FB}}$ mice compared with WT mice

Published by Bioscientifica Ltd. 

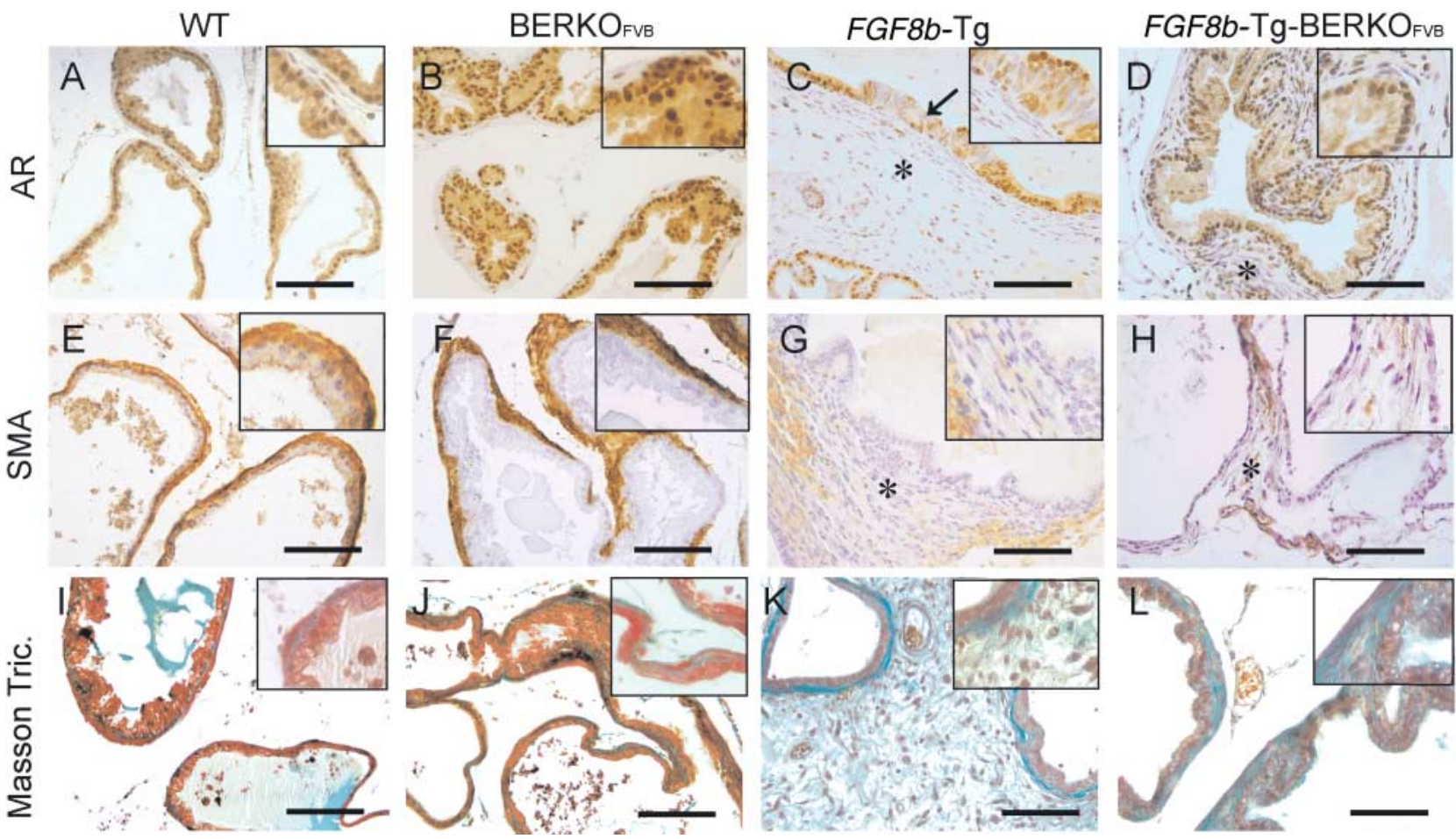

\section{Figure 3}

Immunohistochemical (IHC) staining of AR (A, B, C, and D) and SMA (E, F, G, and $\mathrm{H}$ ) and Masson's trichrome staining ( $\mathrm{I}, \mathrm{J}, \mathrm{K}$, and $\mathrm{L}$ ) in the VPs of 10-15-month-old WT, BERKO ${ }_{\mathrm{FVB}}, F G F 8 b-\mathrm{Tg}$, and FGF8b-Tg-BERKO $\mathrm{FVB}_{\mathrm{B}}$ mice. (A) A representative image of AR staining in the VP of a WT mouse in which $100 \%$ of the epithelial cells and $40 \%$ of the stromal cells are AR-positive. (B) VP of a BERKO ${ }_{F V B}$ mouse in which epithelium and stroma showed similar staining patterns for AR to those of the WT mice. (C) The prostate of an FGF8b-TG mouse in which the PIN lesion (arrow) and hypercellular stroma (*) contained a decreased frequency of AR-positive cells compared with WT mice. (D) An FGF8b-Tg-BERKO ${ }_{\text {FVB }}$ mouse VP with hypercellular epithelium and stroma $\left(^{*}\right)$ with $\sim 100$ and $50 \%$ AR-positive cells respectively.

(E) A representative figure showing SMA staining in the VP of a WT mouse (F) and SMA staining in the VP of a BERKO mouse. (G) The VP of an FGF8b-Tg mouse with wide areas of SMA-negative hypercellular and atypical stroma surrounding the acini $\left(^{*}\right)$. (H) The VP of an FGF8bTg-BERKO ${ }_{\mathrm{FVB}}$ mouse showing the SMA-negative hypercellular stroma $\left(^{*}\right)$. (I) Masson's trichrome staining for collagen in the VP of a WT mouse. (J) Masson's trichrome staining in the VP of a $\mathrm{BERKO}_{\mathrm{FVB}}$ mouse showing a similar staining pattern to that in the WT mouse. (K) The VP of an FGF8bTg mouse with hypercellular and atypical stroma displaying wide areas of blue-green staining and collagen-rich stroma. (L) The VP of an FGF8b-

Tg-BERKO ${ }_{F V B}$ mouse, showing an increased amount of blue-green staining and collagen-rich stroma around the prostatic acini. These images were obtained using a $20 \times$ objective, and the insets show a $2 \times$ magnification of these images. The scale bars represent $100 \mu \mathrm{m}$.

$P=0.0029$ respectively). In the VPs of the $\mathrm{BERKO}_{\mathrm{FVB}}$ mice, the expressions of Fgfr $1 c$ and Fgfr2c mRNAs were similar to those of WT mice. There were no significant differences in the expressions of $F g f r 1 b$ and $F g f r 2 b$ mRNAs in the VPs of different mouse groups. The expressions of $F g$ fr $3 b$ and $F g f r 3 c$ mRNAs could not be quantified because the levels of these mRNAs were below the detection limit of qRT-PCR.

To examine whether the deficiency of ER $\beta$ expression in BERKO $_{\mathrm{FVB}}$ and $F G F 8 b$-TG-BERKO ${ }_{\mathrm{FVB}}$ mice affected the expression of other steroid hormone receptors in the prostate, the expression of ER $\alpha$ and AR was analyzed by qRT-PCR (Fig. 4). The upregulation of the AR in BERKOs has been reported previously by Imamov et al. (2004). Compared with WT mice, the expression of $A r$ mRNA in http://erc.endocrinology-journals.org DOI: 10.1530/ERC-13-0480
(C) 2014 Society for Endocrinology Printed in Great Britain 

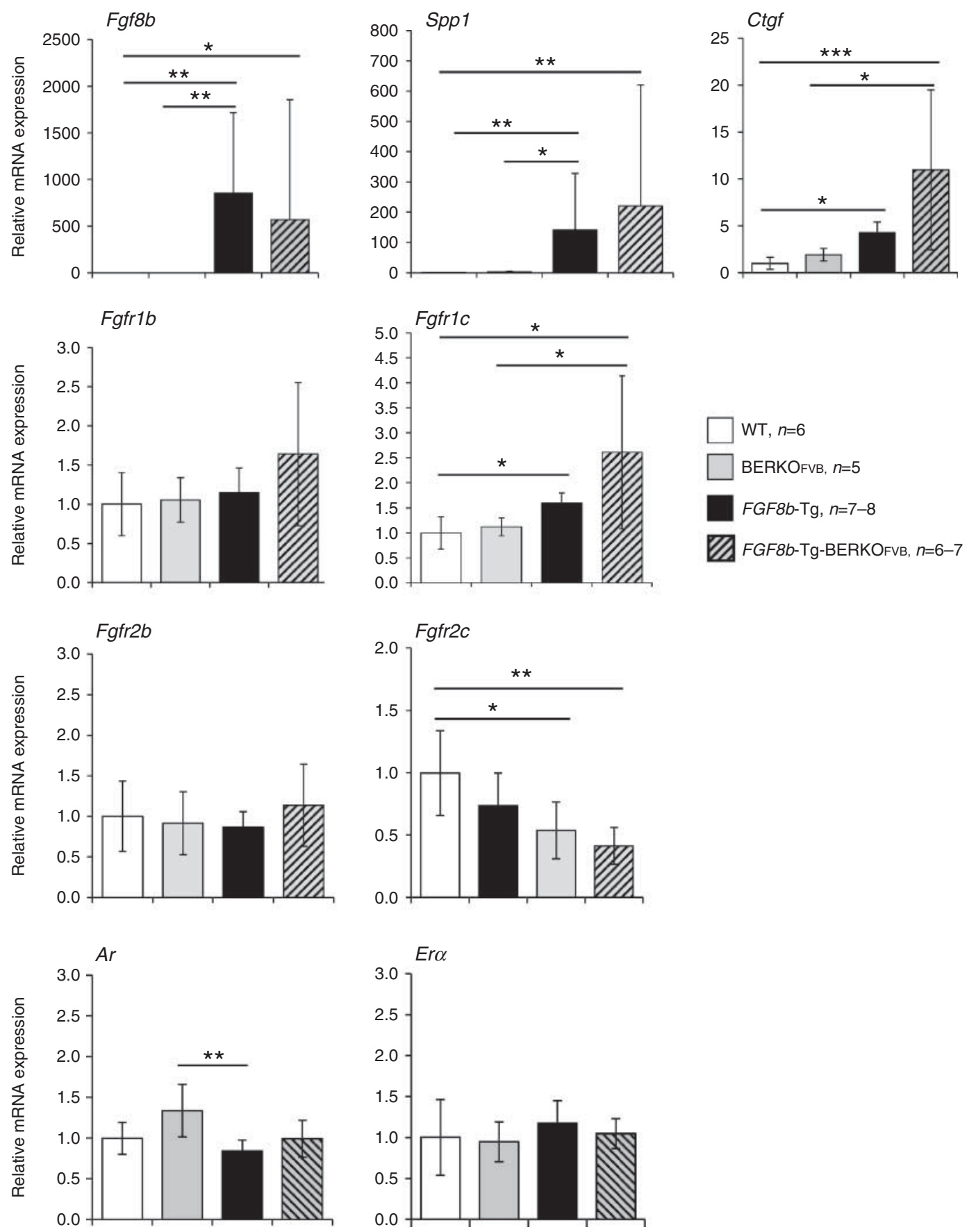

\section{Figure 4}

The expression of the indicated genes in the VPs of 12-16-month-old WT, BERKO, FGF8b-Tg, and FGF8b-Tg-BERKO ${ }_{\mathrm{FVB}}$ mice as analyzed by qRT-PCR. $\beta$-actin was used as a reference gene for data normalization, and the relative values were measured using the WT average as a reference

the prostate was slightly upregulated in $\mathrm{BERKO}_{\mathrm{FVB}}$ mice and slightly downregulated in FGF8b-Tg mice, but these differences were not statistically significant. However, the difference between the level of $A r$ mRNA in the prostates artificially set at 1 . The mean values and S.D.s are shown. The differences between groups were tested by one-way ANOVA corrected with Tukey's multiple comparison test or by a Kruskal-Wallis test corrected with Dunn's multiple comparison test. ${ }^{*} P<0.05, * * P<0.01, * * * P<0.001$.

of BERKO $_{\mathrm{FVB}}$ and $F G F 8 b$-Tg mice was statistically significant (ANOVA, $P=0.0032$ ). No significant differences were detected in the mRNA levels of Er $\alpha$ between any of the mouse groups. 
WT, $n=6 \quad \boldsymbol{B}$ BERKOFVB, $n=5 \quad \boldsymbol{\Delta}$ FGF8b-Tg, $n=8 \quad \boldsymbol{\nabla}$ FGF8b-Tg-BERKOFVB, $n=7$
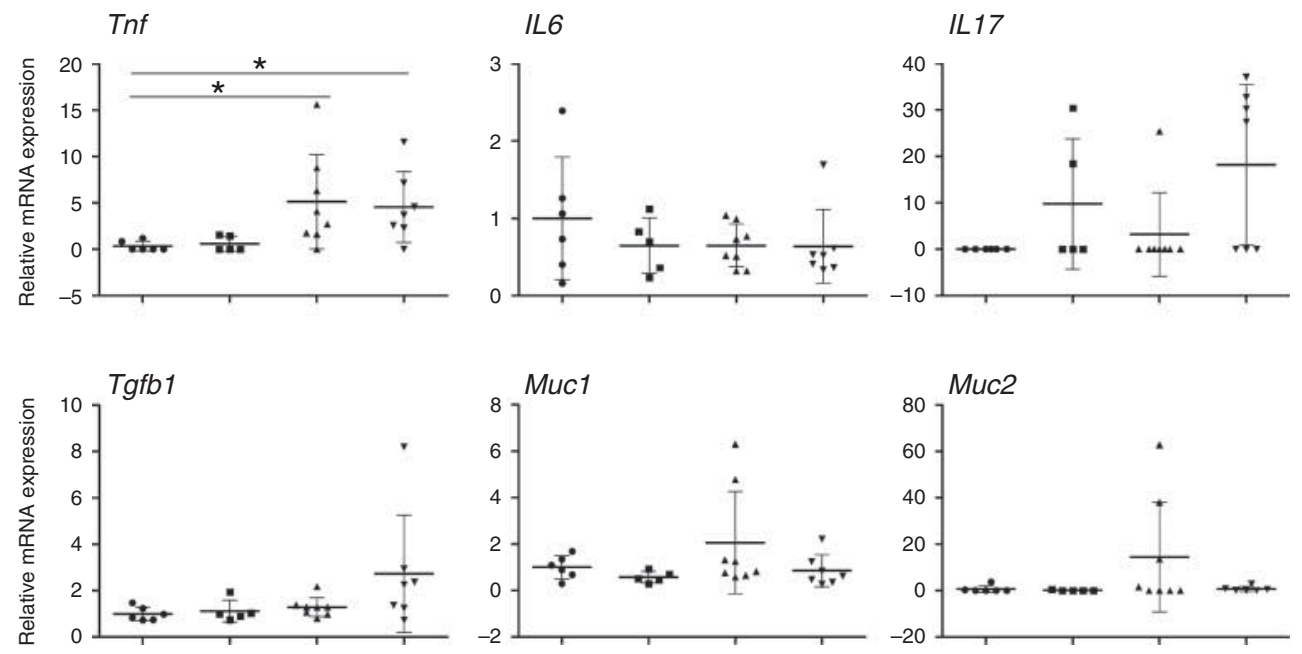

\section{Figure 5}

The expression of genes for cytokines (Tnf, I/6, and IL17a), prostate cancerpromoting factors ( $T g f b 1)$, and proteins related to the mucin-secreting phenotype (Muc1 and Muc2) as analyzed by qRT-PCR. $\beta$-actin was used as a reference gene for data normalization, and the relative values were calculated using the WT average as a reference value artificially set at 1 . In case of I/17 qRT-PCR, the average of all the CT value data was used as a reference artificially set at 1 because no signal could be detected in any of the WT prostates. The mean values and S.D.S are shown. The differences between groups were tested by one-way ANOVA corrected with Tukey's multiple comparison test or by a Kruskal-Wallis test corrected with Dunn's multiple comparison test. ${ }^{*} P<0.05$.
As prostatic inflammation was frequent among the mouse groups, the mRNA levels of several proinflammatory cytokines, such as tumor necrosis factor $\alpha$ (Tnf) and interleukins 6 (Il6) and 17 (Il17a), were analyzed by qRT-PCR (Fig. 5). Compared with WT mice, the level of Tnf mRNA was significantly upregulated in the prostates of FGF8b-Tg and FGF8b-Tg-BERKO ${ }_{\text {FVB }}$ mice (Kruskal-Wallis test, $P=0.0347$ and $P=0.044$ respectively). The expression of IL17a mRNA was undetectable in most of the samples (19 out of 26 samples, including all the WT prostates) but was upregulated in the prostate of some of the $\mathrm{BERKO}_{\mathrm{FVB}}$ and FGF8b-Tg-BERKO $\mathrm{FVB}_{\text {B }}$ mice and in one FGF8b-Tg mouse. However, no statistically significant differences between the groups were found for the Il6 or $I l 17$ mRNA levels.

Finally, the expression of several markers associated with a mucinous phenotype and/or prostate cancer progression, such as mucin 1 (Muc1) and mucin 2 (Muc2) and transforming growth factor $\beta 1$ (Tgfb1), was analyzed using qRT-PCR (Fig. 5). The prostates of FGF8b-Tg-BERKO ${ }_{\text {FVB }}$ mice showed a tendency toward higher levels of $T g f b 1$ compared with other groups, but due to large interindividual variation, the difference was not statistically significant (Kruskal-Wallis test, $P=0.12$ ). The mean level of both Muc1 and Muc2 mRNAs was highest in the prostate of $F G F 8 b$-Tg mice, but there were no significant differences in the level of Muc1 or Muc2 mRNAs between the mouse groups.

\section{Discussion}

Several studies have provided evidence for antiproliferative and differentiation-promoting effects of ER $\beta$ and tumorigenic effects of ER $\alpha$ in the prostate (Prins et al. 2001, Risbridger et al. 2001, McPherson et al. 2007, Savolainen et al. 2007, Ricke et al. 2008, Hartman et al. 2012, Kawashima \& Nakatani 2012, Dey et al. (In Press)). Recently, the anti-tumorigenic effect of ER $\beta$ was supported by results from a study, which compared the incidence of prostate tumorigenesis in genistein- and casein-fed transgenic adenocarcinoma of the mouse prostate (TRAMP), BERKO-TRAMP, and ERKO-TRAMP mice (Slusarz et al. 2012). In the current study, we examined how the deficiency of ER $\beta$ affects prostate tumorigenesis that had been previously observed in FGF8b-Tg mice (Elo et al. 2010) by crossing FGF8b-Tg mice with BERKO FVB $_{\text {mice. }}$ We examined the hypothesis that two genomic, putative tumor-promoting modifications might generate a model with accelerated or more advanced prostate tumorigenesis, as has been reported previously for several 
mouse models bearing more than one genomic modification (Jeet et al. 2010, Ittmann et al. 2013).

Consistent with results described in our previous report, a high frequency of the 1-year-old FGF8b-Tg mouse prostates contained epithelial and stromal hypercellularities, inflammation, and mPIN lesions. In addition, some $F G F 8 b$-Tg mouse prostates contained cancers (adenocarcinoma, sarcoma, or carcinosarcoma) (Elo et al. 2010). The prostate of a 1-year-old $\mathrm{BERKO}_{\mathrm{FVB}}$ mouse contained relatively mild changes, including epithelial hypercellularity and inflammation. This is in contrast to the results from a study by Weihua et al. (2001), which reported a higher frequency of more pronounced hyperplasia in the prostates of their BERKO mice. This result is interesting because the $\mathrm{BERKO}_{\mathrm{FVB}}$ mice used in this study initially originated from the same colony as those studied by Weihua et al. (2001), but they were bred in a different genetic background. However, other research groups have not detected any changes in the prostate histology of different BERKO mouse models (Dupont et al. 2000, Prins et al. 2001, Antal et al. 2008), and therefore, the prostate phenotypes of BERKO mice have remained a subject of controversy.

In addition to hyperplasia, previous studies have shown increased proliferation, decreased apoptosis, increased AR expression, and an increased number of p63-positive, incompletely differentiated epithelial cells in the prostate of the BERKO mice (in a C57BL background) (Weihua et al. 2001, Imamov et al. 2004). Our results regarding the expression pattern of p63 differ from those described by Imamov et al. (2004) because even though we noticed a tendency toward a higher frequency of p63positive cells in the hypercellular foci of BERKO ${ }_{\mathrm{FVB}}$ prostate epithelium, the overall frequency of p63-positive cells in the epithelium was not significantly altered. This may be explained by the relatively sparsely located hypercellular foci in the prostate epithelium of our BERKO $_{\mathrm{FVB}}$ mice. According to our results, including the IHC staining and qRT-PCR analysis of the AR, the level of Ar mRNA or protein was not significantly increased in the prostates of $\mathrm{BERKO}_{\mathrm{FVB}}$ mice compared with those of WT mice, but interestingly, the level of $A r$ mRNA was significantly higher in the prostates of $\mathrm{BERKO}_{\mathrm{FVB}}$ mice compared with those of $F G F 8 b$-Tg mice; this may be due to a previously reported decreased level of AR in the PIN lesions and in the hypercellular stroma of the $F G F 8 b$-Tg mice (Elo et al. 2010).

In contrast to the results expected according to the original hypothesis, the $F G F 8 b$-Tg-BERKO ${ }_{\mathrm{FVB}}$ mice did not contain more mPIN lesions or more advanced neoplastic changes than the FGF8b-Tg mice. The epithelial and stromal hypercellularities were, in fact, slightly more frequent in the prostates of $F G F 8 b$-Tg-BERKO $\mathrm{FVB}_{\mathrm{FB}}$ mice when compared with $F G F 8 b$-Tg mice, while the hypercellular changes, especially in the stroma, were less extensive in the $F G F 8 b$-Tg-BERKO ${ }_{\text {FVB }}$ mice and tended to contain less frequently atypical cells. The cellular composition of hypercellular stroma also seemed to be different in these two mouse groups. In addition, unlike in the $F G F 8 b$-Tg mice, malignant changes were not found in the prostates of $F G F 8 b$-Tg-BERKO ${ }_{\mathrm{FVB}}$ mice. Taken together, these data indicate that ER $\beta$ does not seem to protect against the development of atypical hypercellularity in the epithelium and stroma nor does it function as a tumor suppressor in the prostates of $F G F 8 b$-Tg mice. Our results are not consistent with previous results regarding the role of ER $\beta$, which have shown that ER $\beta$ agonists can induce apoptosis in the epithelium and stroma of prostate cancer and BPH (McPherson et al. 2010).

It is interesting that mucinous metaplasia, as indicated by mucin-secreting, PAS-positive cells in the prostate epithelium, was clearly more frequent in $F G F 8 b$-Tg-BERKO $\mathrm{FVB}_{\mathrm{F}}$ mice than in any of the other mouse groups studied. This indicates that even if the structural changes in the prostate histology of $\mathrm{BERKO}_{\mathrm{FVB}}$ mice were mild, the lack of ER $\beta$ combined with overexpression of $F G F 8 b$ influences the differentiation of the epithelial cells. An increased frequency of mucinous metaplasia has been reported previously in the prostates of old FGF8b-Tg mice (Elo et al. 2010), but a lack of ER $\beta$ appears to make the epithelial cells more likely to adopt the mucin-secreting, goblet-cell-like phenotype. The significance of these mucin-secreting cells in the prostate is unclear, but in human prostate, benign lesions with mucin-secreting cells and mucinous adenocarcinoma, a rare form of prostate cancer, have both been described (Bohman \& Osunkoya 2012). Interestingly, mucinous metaplasia in association with prostatic adenocarcinoma has been reported for several genetically modified mouse models (Ittmann et al. 2013).

We have reported previously that prostatic inflammation, indicated by aggregates of several types of inflammatory cells such as T-cells, B-cells, and macrophages in the stroma, was frequent in FGF8b-Tg mice (Elo et al. 2010). Our current results indicated a tendency towards an increased frequency of inflammation in the prostates of $F G F 8 b$-Tg-BERKO ${ }_{\mathrm{FVB}}$ mice than in those of the $F G F 8 b$-Tg mice, indicating that a deficiency of ER $\beta$ could facilitate the formation of inflammatory lesions in the FGF8b-Tg mice. This is consistent with results from

Published by Bioscientifica Ltd. 
previous animal studies; it has been reported that ER $\alpha$ mediates neonatal estrogen-treatment-induced prostatic inflammation (Prins et al. 2001), and the anti-inflammatory effects of ER $\beta$ have been demonstrated in a rat model of inflammatory bowel disease (Harris et al. 2003) and in luteinizing hormone receptor knockout (LuRKO) mice (Savolainen et al. 2007). Furthermore, Prins \& Korach (2008) have reported massive T-cell infiltration in the prostates of BERKO mice. This study did not find any statistically significant differences in the mRNA levels of proinflammatory cytokines (Il6, Il17a and Tnf) between the prostates of $\mathrm{WT}$ and $\mathrm{BERKO}_{\mathrm{FVB}}$ mice or between $F G F 8 b$-Tg and $F G F 8 b$-Tg-BERKO ${ }_{\mathrm{FVB}}$ mice. However, a trend toward higher $I l 17 a$ levels in $\mathrm{BERKO}_{\mathrm{FVB}}$ and Tg-BERKO $\mathrm{FVB}_{\mathrm{B}}$ mice was observed. In addition, Tnf was upregulated in both $F G F 8 b$-Tg and FGF8b-Tg-BERKO ${ }_{\text {FvB }}$ prostates. This upregulation is most probably associated with the ongoing inflammatory process. TNF is a multifunctional protein that can be secreted by several cell types, especially by macrophages, and, depending on conditions, it can promote inflammation, cell proliferation, and tumorigenesis or induce apoptosis (Balkwill 2009).

As expected, the expression of the mRNA for FGF8b and two genes (Spp1 and Ctgf) previously found to be upregulated in the prostate and epididymis of $F G F 8 b$-Tg mice (Elo et al. 2010, 2012) was increased in the prostate of $F G F 8 b$-Tg-BERKO $\mathrm{FVB}_{\mathrm{FB}}$ mice. Interestingly, upregulation of the mRNA for $F g f r 1 c$ and downregulation of the mRNA for $F g f r 2 c$ were found in the prostates of $F G F 8 b$-Tg and FGF8bTg-BERKO $\mathrm{FVB}_{\mathrm{B}}$ mice. This observation is consistent with our previous results in S115 mouse mammary tumor cells, MCF7 breast cancer cells (Ruohola et al. 1995, Tarkkonen et al. 2012), and the epididymides of FGF8b-Tg mice (Elo et al. 2012), indicating that FGF signaling regulates the expression of FGFRs. Results described in a previous report have demonstrated that FGF8 upregulates the expression of Fgfr1 in the neuronal cells (Mott et al. 2010). Importantly, the upregulation of $F g f r 1 c$ expression provides a means for the enhancement of FGF signaling because $F G F 8 b$ can efficiently bind and activate the c-isoforms, but not the b-isoforms, of FGFRs (Zhang et al. 2006). The induction of Fgfr $1 c$ in the prostate of FGF8b-Tg mice may also explain the similarities previously observed between the prostatic malignancies (mixed neoplasias of epithelium and stroma) of FGF8b-Tg and FGFR1-Tg mice (Acevedo et al. 2007, Elo et al. 2010). The downregulation of Fgfr $2 c$ mRNA in the prostates of FGF8b-Tg and FGF8bTg-BERKO $\mathrm{FVB}_{\mathrm{B}}$ mice is also consistent with the development of prostatic hyperplasia and PIN lesions because results from previous studies have shown that, unlike the activation of FGFR1c, the activation of FGFR2c does not induce the development of hyperplasias or dysplasias in the prostate epithelium (Freeman et al. 2003).

It is probable that environmental and genetic factors have had a considerable influence on the variable prostate phenotypes of BERKO mouse lines studied by different laboratories (Dupont et al. 2000, Prins et al. 2001, Weihua et al. 2001, Antal et al. 2008). Our BERKO $\mathrm{FVB}$ model is the first one, to our knowledge, generated in the FVB/N mouse strain, whereas others were made in the C57BL strain. There is evidence that different mouse strains have differential susceptibilities to prostate tumorigenesis (Bianchi-Frias et al. 2007). It should also be noted that the $\mathrm{BERKO}_{\mathrm{FVB}}$ model used in this study is not a complete knockout model because it was generated by insertion of NEO-cassette into exon 3 of the $\operatorname{Er} \beta$ gene (Krege et al. 1998). The presence of shorter forms of $\operatorname{Er} \beta$ mRNA in BERKO mice, which resulted from alternative splicing of Er $\beta$ mRNA, has been described previously with respect to the ovaries of BERKO mice (Krege et al. 1998, Dupont et al. 2000). Our experiments demonstrated similar shorter forms of $\operatorname{Er} \beta$ mRNA and IHC-based evidence for a protein product (truncated ER $\beta$ ) for the first time, to our knowledge, in the prostates of BERKO mice (Supplementary Figure 2, see section on supplementary data given at the end of this article). According to Krege et al. (1998) and our results, two of these $\operatorname{Er} \beta \mathrm{KO}$ mRNAs $\left(\operatorname{Er} \beta \mathrm{KO}_{1}\right.$ and $\left.\operatorname{Er} \beta \mathrm{KO}_{2}\right)$ lack the disrupted exon 3 and contain early stop codons in the exon 4. They would therefore be translated into protein products lacking the DNA-binding domain (DBD) and the ligand-binding domain (LBD) (Supplementary Figure 2). The third $\operatorname{Er} \beta \mathrm{KO}$ mRNA $\left(\operatorname{Er} \beta \mathrm{KO}_{3}\right.$, Krege et al. 1998), which seemed to be present only occasionally at low levels in the prostate of $\mathrm{BERKO}_{\mathrm{FVB}}$ mice, lacks only exons 3 and 4 . It would thus be translated into a protein product devoid of the DBD but containing the AF1 and AF2 (and the LDB) domains. These shortened $\operatorname{Er} \beta \mathrm{KO}$ protein products are not capable of exerting the classical functions of the ER $\beta$, but they may, especially the $\operatorname{Er} \beta \mathrm{KO}_{3}$ product, possess some of the non-classical functions of ER $\beta$, such as those mediated by the activation of AP1 sites (Price et al. 2001).

One feature that complicates our understanding of the function of ER $\beta$ is the presence of functionally different isoforms of ER $\beta$ in the prostate. In a pattern consistent with the results described in previous studies of ER $\beta$ expression in the rat prostate (Petersen et al. 1998, Hanstein et al. 1999), we observed the expression of $\operatorname{Er} \beta$ isoforms 1 (' $m E r \beta 2$, wt isoform') and $2(m E r \beta 2)$ in the prostates of WT mice (Supplementary Figure 2a).

Published by Bioscientifica Ltd. 
The structure and nomenclature of ER $\beta$ isoforms differ between mice and humans, and for example, hER $\beta 2$ and mER $\beta 2$ are not homologs (Lu et al. 1998, Moore et al. 1998). In fact, normal human tissues do not express an ER $\beta$ isoform homologous to the mER $\beta 2$ isoform (Lu et al. 1998), but a corresponding isoform (different from hER $\beta 1$, hER $\beta 2$, hER $\beta 3$, hER $\beta 4$, and hER $\beta 5$ ) is expressed in some human cancer cell lines (Hanstein et al. 1999). The mER $\beta 2$ has ligand- and coactivator-binding properties that are different from mER $\beta 1$ (Zhao et al. 2005), but its physiological function is unclear. It has been suggested that mER $\beta 2$ acts as a negative regulator of ER $\alpha$ (Zhao et al. 2005) and/or ERß1 (Lu et al. 2000). In humans, the different isoforms of ER $\beta$ are functionally different and have differential, even opposite roles in prostate tumorigenesis (Leung et al. 2010, Dey et al. 2012, Kawashima \& Nakatani 2012), which may partly explain conflicting results regarding the role of ER $\beta$ in the prostate.

In conclusion, our results from $F G F 8 b$-Tg-BERKO ${ }_{\mathrm{FVB}}$ mice indicate that ER $\beta$ plays a role in the differentiation of prostatic epithelium and may have a protective effect against prostatic inflammation. These effects of ER $\beta$ deficiency were more obvious when it was combined with the overexpression of $F G F 8 b$, whereas the prostates of $\mathrm{BERKO}_{\mathrm{FVB}}$ mice displayed only mild changes. Surprisingly, prostate tumorigenesis was not accelerated in the FGF8bTg-BERKO $\mathrm{FVB}_{\mathrm{FB}}$ mice compared with the $F G F 8 b$-Tg mice, and our results do not support a tumor-suppressive role for ER $\beta$ in this mouse model. The mild phenotype of $\mathrm{BERKO}_{\mathrm{FVB}}$ could be partly explained by the presence of shorter ER $\beta$ forms in the $\mathrm{BERKO}_{\mathrm{FVB}}$ prostates that may have some of the non-classical functions of intact ER $\beta$ (Kushner et al. 2000, Price et al. 2001).

On the whole, ER $\beta$ may have different roles in the different phases of prostate development and the different phases of prostate tumorigenesis (Nelson et al. (In Press)). Therefore, a conditional inducible knockout model of ER $\beta$ would be required to examine the effect of $\operatorname{ER} \beta$ abrogation in prostate tumorigenesis completely and to eliminate the potential consequences of the lack of a functional receptor during prostate maturation. The function and expression of the different ER $\beta$ isoforms in prostate cancer should be examined in future studies because it is possible that altered combination of these isoforms influences tumorigenesis and tumor progression.

\section{Supplementary data}

This is linked to the online version of the paper at http://dx.doi.org/10.1530/ ERC-13-0480.

http://erc.endocrinology-journals.org DOI: $10.1530 /$ ERC-13-0480

(c) 2014 Society for Endocrinology Printed in Great Britain
Declaration of interest

The authors declare that there is no conflict of interest that could be perceived as prejudicing the impartiality of the research reported.

\section{Funding}

This study was financially supported by the Finnish Cancer Foundation, the Sigrid Jusélius Foundation, the Finnish Cultural Foundation, the Turku University Foundation, the Finnish Concordia Fund, the Finnish-Norwegian Medicine foundation, the Cancer Association of South-Western Finland, and the Faculty of Medicine, University of Turku, Finland.

\section{Acknowledgements}

The authors would like to thank Soili Jussila and Liudmila Shumskaya for their technical assistance and Tero Vahlberg for assistance with statistical tests.

\section{References}

Acevedo VD, Gangula RD, Freeman KW, Li R, Zhang Y, Wang F, Ayala GE, Peterson LE, Ittmann M \& Spencer DM 2007 Inducible FGFR-1 activation leads to irreversible prostate adenocarcinoma and an epithelial-to-mesenchymal transition. Cancer Cell 12 559-571. (doi:10.1016/j.ccr.2007.11.004)

Antal MC, Krust A, Chambon P \& Mark M 2008 Sterility and absence of histopathological defects in nonreproductive organs of a mouse ER $\beta$ null mutant. PNAS 105 2433-2438. (doi:10.1073/pnas.0712029105)

Balkwill F 2009 Tumour necrosis factor and cancer. Nature Reviews. Cancer 9 361-371. (doi:10.1038/nrc2628)

Bianchi-Frias D, Pritchard C, Mecham BH, Coleman IM \& Nelson PS 2007 Genetic background influences murine prostate gene expression: implications for cancer phenotypes. Genome Biology 8 R117. (doi:10.1186/gb-2007-8-6-r117)

Bohman KD \& Osunkoya AO 2012 Mucin-producing tumors and tumorlike lesions involving the prostate: a comprehensive review. Advances in Anatomic Pathology 19 374-387. (doi:10.1097/PAP.0b013e318271a361)

Bonkhoff H, Fixemer T, Hunsicker I \& Remberger K 1999 Estrogen receptor expression in prostate cancer and premalignant prostatic lesions. American Journal of Pathology 155 641-647. (doi:10.1016/S0002-9440 (10)65160-7)

Chen M, Hsu I, Wolfe A, Radovick S, Huang K, Yu S, Chang C, Messing EM \& Yeh S 2009 Defects of prostate development and reproductive system in the estrogen receptor- $\alpha$ null male mice. Endocrinology 150 251-259. (doi:10.1210/en.2008-0044)

Dey P, Jonsson P, Hartman J, Williams C, Strom A \& Gustafsson JA 2012 Estrogen receptors $\beta 1$ and $\beta 2$ have opposing roles in regulating proliferation and bone metastasis genes in the prostate cancer cell line PC3. Molecular Endocrinology 12 1991-2003. (doi:10.1210/ me.2012.1227)

Dey P, Strom A \& Gustafsson JA (In Press) Estrogen receptor $\beta$ upregulates FOXO3a and causes induction of apoptosis through PUMA in prostate cancer. Oncogene. doi:10.1038/onc.2013.384

Dupont S, Krust A, Gansmuller A, Dierich A, Chambon P \& Mark M 2000 Effect of single and compound knockouts of estrogen receptors $\alpha(E R \alpha)$ and $\beta$ (ER $\beta)$ on mouse reproductive phenotypes. Development 127 4277-4291.

Ellem SJ \& Risbridger GP 2009 The dual, opposing roles of estrogen in the prostate. Annals of the New York Academy of Sciences 1155 174-186. (doi:10.1111/j.1749-6632.2009.04360.x) 
Elo TD, Valve EM, Seppänen JA, Vuorikoski HJ, Mäkelä SI, Poutanen M, Kujala PM \& Härkönen PL 2010 Stromal activation associated with development of prostate cancer in prostate-targeted fibroblast growth factor 8b transgenic mice. Neoplasia 12 915-927. (doi:10.1593/neo. 10776)

Elo T, Sipilä P, Valve E, Kujala P, Toppari J, Poutanen M \& Härkönen P 2012 Fibroblast growth factor $8 \mathrm{~b}$ causes progressive stromal and epithelial changes in the epididymis and degeneration of the seminiferous epithelium in the testis of transgenic mice. Biology of Reproduction 157 1-12. (doi:10.1095/biolreprod.111.097352)

Fixemer T, Remberger K \& Bonkhoff H 2003 Differential expression of the estrogen receptor $\beta$ (ER $\beta$ ) in human prostate tissue, premalignant changes, and in primary, metastatic, and recurrent prostatic adenocarcinoma. Prostate 54 79-87. (doi:10.1002/pros.10171)

Freeman KW, Welm BE, Gangula RD, Rosen JM, Ittmann M, Greenberg NM \& Spencer DM 2003 Inducible prostate intraepithelial neoplasia with reversible hyperplasia in conditional FGFR1-expressing mice. Cancer Research 63 8256-8263.

Greene GL, Gilna P, Waterfield M, Baker A, Hort Y \& Shine J 1986 Sequence and expression of human estrogen receptor complementary DNA. Science 231 1150-1154. (doi:10.1126/science.3753802)

Hanstein B, Liu H, Yancisin MC \& Brown M 1999 Functional analysis of a novel estrogen receptor- $\beta$ isoform. Molecular Endocrinology 13 129-137. (doi:10.1210/mend.13.1.0234)

Härkönen PL \& Mäkelä SI 2004 Role of estrogens in development of prostate cancer. Journal of Steroid Biochemistry and Molecular Biology 92 297-305. (doi:10.1016/j.jsbmb.2004.10.016)

Harris HA, Albert LM, Leathurby Y, Malamas MS, Mewshaw RE, Miller CP, Kharode YP, Marzolf J, Komm BS, Winneker RC et al. 2003 Evaluation of an estrogen receptor- $\beta$ agonist in animal models of human disease. Endocrinology 144 4241-4249. (doi:10.1210/en.2003-0550)

Hartman J, Strom A \& Gustafsson JA 2012 Current concepts and significance of estrogen receptor $\beta$ in prostate cancer. Steroids $\mathbf{7 7}$ 1262-1266. (doi:10.1016/j.steroids.2012.07.002)

Horvath LG, Henshall SM, Lee CS, Head DR, Quinn DI, Mäkelä S, Delprado W, Golovsky D, Brenner PC, O’Neill G et al. 2001 Frequent loss of estrogen receptor- $\beta$ expression in prostate cancer. Cancer Research 61 5331-5335.

Imamov O, Morani A, Shim GJ, Omoto Y, Thulin-Andersson C, Warner M $\&$ Gustafsson JA 2004 Estrogen receptor $\beta$ regulates epithelial cellular differentiation in the mouse ventral prostate. PNAS $1019375-9380$. (doi:10.1073/pnas.0403041101)

Ittmann M, Huang J, Radaelli E, Martin P, Signoretti S, Sullivan R, Simons BW, Ward JM, Robinson BD, Chu GC et al. 2013 Animal models of human prostate cancer: the consensus report of the New York meeting of the Mouse Models of Human Cancers Consortium Prostate Pathology Committee. Cancer Research 73 2718-2736. (doi:10.1158/0008-5472.CAN-12-4213)

Jeet V, Russell PJ \& Khatri A 2010 Modeling prostate cancer: a perspective on transgenic mouse models. Cancer Metastasis Reviews 29 123-142. (doi:10.1007/s10555-010-9212-9)

Kawashima H \& Nakatani T 2012 Involvement of estrogen receptors in prostatic diseases. International Journal of Urology 19 512-522 author reply 522-3. (doi:10.1111/j.1442-2042.2012.02987.x)

Krege JH, Hodgin JB, Couse JF, Enmark E, Warner M, Mahler JF, Sar M, Korach KS, Gustafsson JA \& Smithies O 1998 Generation and reproductive phenotypes of mice lacking estrogen receptor $\beta$. PNAS 95 15677-15682. (doi:10.1073/pnas.95.26.15677)

Kuiper GG, Enmark E, Pelto-Huikko M, Nilsson S \& Gustafsson JA 1996 Cloning of a novel receptor expressed in rat prostate and ovary. PNAS 93 5925-5930. (doi:10.1073/pnas.93.12.5925)

Kushner PJ, Agard DA, Greene GL, Scanlan TS, Shiau AK, Uht RM \& Webb P 2000 Estrogen receptor pathways to AP-1. Journal of Steroid Biochemistry and Molecular Biology 74 311-317. (doi:10.1016/S09600760(00)00108-4)
Lau KM, LaSpina M, Long J \& Ho SM 2000 Expression of estrogen receptor (ER)- $\alpha$ and ER- $\beta$ in normal and malignant prostatic epithelial cells: regulation by methylation and involvement in growth regulation. Cancer Research $603175-3182$.

Leav I, Lau KM, Adams JY, McNeal JE, Taplin ME, Wang J, Singh H \& Ho SM 2001 Comparative studies of the estrogen receptors $\beta$ and $\alpha$ and the androgen receptor in normal human prostate glands, dysplasia, and in primary and metastatic carcinoma. American Journal of Pathology 159 79-92. (doi:10.1016/S0002-9440(10)61676-8)

Leung YK, Mak P, Hassan S \& Ho SM 2006 Estrogen receptor (ER)- $\beta$ isoforms: a key to understanding ER- $\beta$ signaling. PNAS 103 13162-13167. (doi:10.1073/pnas.0605676103)

Leung YK, Lam HM, Wu S, Song D, Levin L, Cheng L, Wu CL \& Ho SM 2010 Estrogen receptor $\beta 2$ and $\beta 5$ are associated with poor prognosis in prostate cancer, and promote cancer cell migration and invasion. Endocrine-Related Cancer 17 675-689. (doi:10.1677/ERC-09-0294)

Li LC, Chui R, Nakajima K, Oh BR, Au HC \& Dahiya R 2000 Frequent methylation of estrogen receptor in prostate cancer: correlation with tumor progression. Cancer Research 60 702-706.

Lu B, Leygue E, Dotzlaw H, Murphy LJ, Murphy LC \& Watson PH 1998 Estrogen receptor- $\beta$ mRNA variants in human and murine tissues. Molecular and Cellular Endocrinology 138 199-203. (doi:10.1016/ S0303-7207(98)00050-1)

Lu B, Leygue E, Dotzlaw H, Murphy LJ \& Murphy LC 2000 Functional characteristics of a novel murine estrogen receptor- $\beta$ isoform, estrogen receptor- $\beta$ 2. Journal of Molecular Endocrinology 25 229-242. (doi:10.1677/jme.0.0250229)

Mäkelä S, Strauss L, Kuiper G, Valve E, Salmi S, Santti R \& Gustafsson JA 2000 Differential expression of estrogen receptors $\alpha$ and $\beta$ in adult rat accessory sex glands and lower urinary tract. Molecular and Cellular Endocrinology 164 109-116. (doi:10.1016/S0303-7207(00)00233-1)

McPherson SJ, Ellem SJ, Simpson ER, Patchev V, Fritzemeier KH \& Risbridger GP 2007 Essential role for estrogen receptor $\beta$ in stromalepithelial regulation of prostatic hyperplasia. Endocrinology 148 566-574. (doi:10.1210/en.2006-0906)

McPherson SJ, Hussain S, Balanathan P, Hedwards SL, Niranjan B, Grant M, Chandrasiri UP, Toivanen R, Wang Y, Taylor RA et al. 2010 Estrogen receptor- $\beta$ activated apoptosis in benign hyperplasia and cancer of the prostate is androgen independent and TNF $\alpha$ mediated. PNAS $\mathbf{1 0 7}$ 3123-3128. (doi:10.1073/pnas.0905524107)

Moore JT, McKee DD, Slentz-Kesler K, Moore LB, Jones SA, Horne EL, Su JL, Kliewer SA, Lehmann JM \& Willson TM 1998 Cloning and characterization of human estrogen receptor $\beta$ isoforms. Biochemical and Biophysical Research Communications 1 75-78. (doi:10.1006/bbrc. 1998.8738)

Mott NN, Chung WC, Tsai PS \& Pak TR 2010 Differential fibroblast growth factor 8 (FGF8)-mediated autoregulation of its cognate receptors, Fgfr 1 and Fgfr3, in neuronal cell lines. PLoS ONE 5 e10143. (doi:10.1371/ journal.pone.0010143)

Muthusamy S, Andersson S, Kim HJ, Butler R, Waage L, Bergerheim U \& Gustafsson JA 2011 Estrogen receptor $\beta$ and 17 $\beta$-hydroxysteroid dehydrogenase type 6 , a growth regulatory pathway that is lost in prostate cancer. PNAS 108 20090-20094. (doi:10.1073/pnas. 1117772108)

Nelson AW, Tilley WD, Neal DE \& Carroll J (In Press) Estrogen receptor $\beta$ in prostate cancer: friend or foe? Endocrine-563 Related Cancer. doi:10.1530/ERC-13-0508

Pasquali D, Staibano S, Prezioso D, Franco R, Esposito D, Notaro A, De Rosa G, Bellastella A \& Sinisi AA 2001 Estrogen receptor $\beta$ expression in human prostate tissue. Molecular and Cellular Endocrinology 178 47-50. (doi:10.1016/S0303-7207(01)00418-X)

Petersen DN, Tkalcevic GT, Koza-Taylor PH, Turi TG \& Brown TA 1998 Identification of estrogen receptor $\beta 2$, a functional variant of estrogen receptor $\beta$ expressed in normal rat tissues. Endocrinology 139 1082-1092. (doi:10.1210/endo.139.3.5840) 
Price RH, Butler CA, Webb P, Uht R, Kushner P \& Handa RJ 2001 A splice variant of estrogen receptor $\beta$ missing exon 3 displays altered subnuclear localization and capacity for transcriptional activation. Endocrinology 142 2039-2049. (doi:10.1210/endo.142.5.8130)

Prins GS \& Birch L 1997 Neonatal estrogen exposure up-regulates estrogen receptor expression in the developing and adult rat prostate lobes. Endocrinology 138 1801-1809. (doi:10.1210/endo.138.5.5106)

Prins GS \& Korach KS 2008 The role of estrogens and estrogen receptors in normal prostate growth and disease. Steroids 73 233-244. (doi:10.1016/ j.steroids.2007.10.013)

Prins GS, Marmer M, Woodham C, Chang W, Kuiper G, Gustafsson JA \& Birch L 1998 Estrogen receptor- $\beta$ messenger ribonucleic acid ontogeny in the prostate of normal and neonatally estrogenized rats. Endocrinology 139 874-883. (doi:10.1210/endo.139.3.5827)

Prins GS, Birch L, Couse JF, Choi I, Katzenellenbogen B \& Korach KS 2001 Estrogen imprinting of the developing prostate gland is mediated through stromal estrogen receptor $\alpha$ : studies with $\alpha$ ERKO and $\beta E R K O$ mice. Cancer Research 61 6089-6097.

Ricke WA, McPherson SJ, Bianco JJ, Cunha GR, Wang Y \& Risbridger GP 2008 Prostatic hormonal carcinogenesis is mediated by in situ estrogen production and estrogen receptor $\alpha$ signaling. FASEB Journal $\mathbf{2 2}$ 1512-1520. (doi:10.1096/fj.07-9526com)

Risbridger G, Wang H, Young P, Kurita T, Wang YZ, Lubahn D, Gustafsson JA \& Cunha G 2001 Evidence that epithelial and mesenchymal estrogen receptor- $\alpha$ mediates effects of estrogen on prostatic epithelium. Developmental Biology 229 432-442. (doi:10.1006/dbio.2000.9994)

Ruohola JK, Valve EM, Vainikka S, Alitalo K \& Härkönen PL 1995 Androgen and fibroblast growth factor (FGF) regulation of FGF receptors in S115 mouse mammary tumor cells. Endocrinology 136 2179-2188. (doi:10.1210/endo.136.5.7536664)

Savolainen S, Pakarainen T, Huhtaniemi I, Poutanen M \& Mäkelä S 2007 Delay of postnatal maturation sensitizes the mouse prostate to testosterone-induced pronounced hyperplasia: protective role of estrogen receptor- $\beta$. American Journal of Pathology 171 1013-1022. (doi:10.2353/ajpath.2007.060979)

Schulze H \& Claus S 1990 Histological localization of estrogen receptors in normal and diseased human prostates by immunocytochemistry. Prostate 16 331-343. (doi:10.1002/pros.2990160408)

Slusarz A, Jackson GA, Day JK, Shenouda NS, Bogener JL, Browning JD, Fritsche KL, Macdonald RS, Besch-Williford CL \& Lubahn DB 2012 Aggressive prostate cancer is prevented in $\mathrm{ER} \alpha \mathrm{KO}$ mice and stimulated in ERßKO TRAMP mice. Endocrinology 153 4160-4170. (doi:10.1210/ en.2012-1030)

Tarkkonen KM, Nilsson EM, Kähkönen TE, Dey JH, HeikkiläJE, Tuomela JM, Liu Q, Hynes NE \& Härkönen PL 2012 Differential roles of fibroblast growth factor receptors (FGFR) 1,2 and 3 in the regulation of S115 breast cancer cell growth. PLoS ONE 7 e49970. (doi:10.1371/journal. pone.0049970)

Torlakovic E, Lilleby W, Torlakovic G, Fossa SD \& Chibbar R 2002 Prostate carcinoma expression of estrogen receptor- $\beta$ as detected by PPG5/10 antibody has positive association with primary Gleason grade and Gleason score. Human Pathology 33 646-651. (doi:10.1053/hupa.2002. 124033)

Tremblay GB, Tremblay A, Copeland NG, Gilbert DJ, Jenkins NA, Labrie F \& Giguere V 1997 Cloning, chromosomal localization, and functional analysis of the murine estrogen receptor $\beta$. Molecular Endocrinology 11 353-365. (doi:10.1210/mend.11.3.9902)

Walton TJ, Li G, McCulloch TA, Seth R, Powe DG, Bishop MC \& Rees RC 2009 Quantitative RT-PCR analysis of estrogen receptor gene expression in laser microdissected prostate cancer tissue. Prostate 69 810-819. (doi:10.1002/pros.20929)

Weihua Z, Mäkelä S, Andersson LC, Salmi S, Saji S, Webster JI, Jensen EV, Nilsson S, Warner M \& Gustafsson JA 2001 A role for estrogen receptor $\beta$ in the regulation of growth of the ventral prostate. PNAS $\mathbf{9 8} 6330-6335$. (doi:10.1073/pnas.111150898)

Windahl SH, Vidal O, Andersson G, Gustafsson JA \& Ohlsson C 1999 Increased cortical bone mineral content but unchanged trabecular bone mineral density in female $E R \beta^{-/-}$mice. Journal of Clinical Investigation 104 895-901. (doi:10.1172/JCI6730)

Zhang X, Ibrahimi OA, Olsen SK, Umemori H, Mohammadi M \& Ornitz DM 2006 Receptor specificity of the fibroblast growth factor family. The complete mammalian FGF family. Journal of Biological Chemistry $\mathbf{2 8 1}$ 15694-15700. (doi:10.1074/jbc.M601252200)

Zhao C, Toresson G, Xu L, Koehler KF, Gustafsson JA \& Dahlman-Wright K 2005 Mouse estrogen receptor $\beta$ isoforms exhibit differences in ligand selectivity and coactivator recruitment. Biochemistry 44 7936-7944. (doi:10.1021/bi047691m)

Zhu X, Leav I, Leung YK, Wu M, Liu Q, Gao Y, McNeal JE \& Ho SM 2004 Dynamic regulation of estrogen receptor- $\beta$ expression by DNA methylation during prostate cancer development and metastasis. American Journal of Pathology 164 2003-2012. (doi:10.1016/S00029440(10)63760-1)

Received in final form 5 June 2014

Accepted 17 June 2014

Made available online as an Accepted Preprint

17 June 2014 http://erc.endocrinology-journals.org DOI: 10.1530/ERC-13-0480
(C) 2014 Society for Endocrinology Printed in Great Britain
Published by Bioscientifica Ltd. 